\title{
Artikel
}

\section{Het waarborgen van duurzaamheid in de Omgevingswet}

\author{
S. van 't Foort BBA LLM (hons) en J. Kevelam LLB*
}

\section{Inleiding}

In juni 2014 werd het wetsvoorstel voor een nieuwe Omgevingswet $(\mathrm{Ow})$ ingediend bij de Tweede Kamer. ${ }^{1}$ Een meer dan zeshonderd pagina's tellende memorie van toelichting $(\mathrm{MvT})^{2}$ geeft uitleg over de nieuwe $\mathrm{Ow}$ die gezien kan worden als de Algemene wet bestuursrecht (Awb) van het omgevingsrecht. ${ }^{3}$ Regionale verschillen, een toenemende aandacht van de samenleving voor de samenhang tussen de opgaven in de fysieke leefomgeving, duurzame ontwikkeling, knelpunten in het huidige omgevingsrecht, en de behoefte aan ruimte voor initiatieven, snelle samenhangende besluitvorming en inzichtelijke regelgeving vormen de belangrijkste maatschappelijke ontwikkelingen die de wetgever nopen tot het schrijven van dit wetsvoorstel en zich in te zetten voor vereenvoudiging en integratie van regelgeving en een beter gebruik van algemene regels. ${ }^{4}$

De Ow beoogt onder andere een heldere normstelling te bewerkstelligen, procedures die uitnodigen tot samenwerking te ontwerpen en helderheid te verschaffen over

* S. (Sander) van 't Foort is als junior onderzoeker verbonden aan de Nyenrode Business University. J. (Julian) Kevelam is masterstudent Staats- en bestuursrecht (track Omgevingsrecht) aan de Universiteit Utrecht. De auteurs danken prof. mr. H.F.M.W. van Rijswick voor haar waardevolle opmerkingen op een conceptversie van dit artikel.

1. Regels over het beschermen en benutten van de fysieke leefomgeving (Omgevingswet), Kamerstukken II 2013/14, 33 962, nr. 1-8.

2. Kamerstukken II 2013/14, 33 962, nr. 3.

3. MvT, p. 6.

4. MvT, p. 11-18. de ruimte voor flexibiliteit. ${ }^{5}$ De twee primaire doelstellingen ${ }^{6}$ van de Ow zijn: (i) het bereiken en in stand houden van een veilige en gezonde fysieke leefomgeving en een goede omgevingskwaliteit; en (ii) het doelmatig beheren, gebruiken en ontwikkelen van de fysieke leefomgeving ter vervulling van maatschappelijke functies. ${ }^{7}$ De wetgever probeert met deze twee doelstellingen twee vliegen in één klap te slaan: versterking van de economie én versterking van de kwaliteit van de fysieke leefomgeving. Deze twee doelstellingen worden samengebracht onder het credo 'ruimte voor ontwikkeling, waarborgen voor kwaliteit' ${ }^{8}$

Het wetsvoorstel beschrijft slechts de hoofdlijnen van het nieuwe omgevingsrecht en een groot deel van de $\mathrm{Ow}$ wordt nog nader uitgewerkt in algemene maatregelen van bestuur (amvb's) en ministeriële regelingen. ${ }^{9}$ De voorgestelde amvb's zijn: (i) het Omgevingsbesluit, (bevat procedurele bepalingen); (ii) Besluit kwaliteit leefomgeving (normeert het overheidshandelen); (iii) een amvb die de algemene regels bevat betreffende activiteiten voor het bouwen; en (iv) een amvb die de

5. MvT, p. 18. Zie ook K.J. de Graaf \& H.D. Tolsma, Flexibiliteit in de Omgevingswet: maatwerk, gelijkwaardigheid en experimenten, $M$ en $\mathrm{R}$ 2014-8.

6. Het wetsvoorstel beschrijft tevens vier verbeterdoelstellingen, te weten: (i) het vergroten van de inzichtelijkheid, de voorspelbaarheid en het gebruiksgemak van het omgevingsrecht (ii) het bewerkstelligen van een samenhangende benadering van de fysieke leefomgeving in beleid, besluitvorming en regelgeving; (iii) het vergroten van de bestuurlijke afwegingsruimte door een actieve en flexibele aanpak mogelijk te maken voor het bereiken van doelen voor de fysieke leefomgeving; en (iv) het versnellen en verbeteren van besluitvorming over projecten in de fysieke leefomgeving (MvT, p. 25). Deze verbeterdoelstellingen vormen op hun beurt weer uitgangspunten welke gebruikt zijn bij het ontwerp van de Ow (MvT, p. 30-33).

7. Art. $1.3 \mathrm{Ow}$

8. MvT, p. 20.

9. MvT, p. 6. 
algemene regels bevat betreffende activiteiten op het gebied van water en milieu. ${ }^{10}$ Uiteindelijk vervangt de Ow 26 wetten, ${ }^{11}$ waarvan een aantal later via afzonderlijke wetsvoorstellen in de Ow zullen worden ingepast, bijvoorbeeld op het gebied van geluid, natuur, bodem en water. $^{12}$

\section{Onderzoeksvraag, methodologie en opbouw van het artikel}

In dit artikel gaan wij in op de vraag hoe duurzaamheidsbelangen in de $\mathrm{Ow}$ zijn gewaarborgd. Om tot beantwoording van deze vraag te komen is de wetsgeschiedenis onderzocht en, waar mogelijk, gebruik gemaakt van aanvullende literatuur. Het doel van dit artikel is niet een gedetailleerd overzicht te geven van de consequenties die de instrumenten van het wetsvoorstel hebben. ${ }^{13}$ Ook moet op deze plaats worden opgemerkt dat, zoals gezegd, de uitvoeringsregelgeving (amvb's, ministeriële regelingen) die voor een goed begrip van de gevolgen van het wetsvoorstel noodzakelijk is, nog niet bekend is. De opbouw van het artikel is als volgt. Na een korte toelichting op een aantal centrale concepten (paragraaf 3), wordt een viertal criteria toegepast om te bepalen hoe duurzaamheid gewaarborgd is in de Ow. Deze vier criteria zijn ontleend aan onderzoek naar duurzaam landgebruik in het omgevingsrecht verricht door het Duitse Helmholtz Centre for Environmental Research in Leipzig. ${ }^{14}$ Deze criteria lenen zich goed voor toepassing op het wetsvoorstel, zoals in het navolgende zal blijken, en geven handen en voeten aan de invulling van het begrip 'duurzaamheid'. Er kunnen uiteraard ook andere criteria een rol spelen bij het bepalen van duurzaamheidsbelangen en in hoeverre deze in wetgeving (kunnen) worden gewaarborgd, maar wij beperken ons tot de vier die gebruikt zijn in het hiervoor genoemde onderzoek. Achtereenvolgens behandelen wij hoe: (i) duurzaamheid is opgenomen in het wetsvoorstel en is uitgewerkt in concrete doelen (paragraaf 4); (ii) integratie

10. MvT, p. 9 en 28-29.

11. Het betreft bijvoorbeeld de Crisis- en herstelwet (Chw), Wet algemene bepalingen omgevingsrecht (Wabo) en de Wet ruimtelijke ordening (Wro).

12. MvT, p. 8 en 29-30. Zie voor wat betreft de natuur- en wateraspecten ook M.M. Kaajan, Natuurbescherming met de Omgevingswet, gaat er nu eindelijk echt iets veranderen?, M en R 2014-8 en H.J.M. Havekes \& W.J. Wensink, Omgevingswet waterproof, TO 2013, nr. 2, p. 68-81.

13. Zie meer algemeen over het wetsvoorstel F.A.G. Groothuijse, D. Korsse \& B.J. Schueler, Kroniek van het omgevingsrecht. De weg naar een nieuwe Omgevingswet, NJB 2014-35, p. 2514-2524, H.W. de Vos, Wetsvoorstel Omgevingswet: op weg naar een nieuwe balans, $M$ en $R$ 2014-8 en J.A.E. Nienhuis, De grote voordelen van de Omgevingswet, TBR 2014/10, p. 920-925

14. De Nederlandse inbreng aan dit onderzoek is geleverd door S. van 't Foort, J. Kevelam, D. Korsse \& H.F.M.W. van Rijswick (Utrecht Centre for Water, Oceans and Sustainability Law). Zie ook ucwosl.rebo. uu.nl. Een digitale versie van de resultaten van het onderzoek is nog niet beschikbaar. en coördinatie wordt bewerkstelligd (paragraaf 5); (iii) monitoring en evaluatie in het wetsvoorstel worden vormgegeven (paragraaf 6); en hoe het publiek bij het nemen van besluiten wordt betrokken (paragraaf 7). ${ }^{15}$ De laatste paragraaf bevat een conclusie en aanbevelingen op grond van onze bevindingen (paragraaf 8).

\section{Begrippenkader en centrale concepten}

In deze paragraaf passeren een aantal centrale begrippen en concepten uit de $\mathrm{Ow}$ de revue. Deze begrippen en concepten vormen de bouwstenen voor dit artikel.

\subsection{Duurzaamheid en duurzame ontwikkeling}

In de memorie van toelichting bij de Ow is duurzaamheid gedefinieerd als 'het waarborgen van de bestaansmogelijkheden van alle mensen op aarde, hier en nu, elders en later' waarbij het onder meer gaat over 'een schoon milieu en een duurzame energievoorziening, het concurrentievermogen van de economie, de toekomstbestendigheid van de zorg, ontwikkelingssamenwerking, onderwijs, cultureel erfgoed, werkgelegenheid [en] het financiële systeem'. ${ }^{16}$ Voor de omschrijving van 'duurzame ontwikkeling' refereert de wetgever aan de gevleugelde definitie van de VN Commissie Brundtland, waarbij het gaat om het voorzien in de behoeften van de huidige generatie zonder toekomstige generaties de mogelijkheid te ontnemen om in hun behoeften te voorzien. ${ }^{17}$ De wetgever koppelt de notie van duurzame ontwikkeling expliciet aan wat bekend staat als de 'triple bottom line' ofwel de drie P's. Het in balans houden van de kwaliteit van de natuurlijke leefomgeving (planet), de economie (profit) en het sociale vermogen van de mens (people) vormt een belangrijk onderdeel van duurzame ontwikkeling. ${ }^{18}$

\subsection{Fysieke leefomgeving}

In de kern gaat het wetsvoorstel in op plaatsgebonden activiteiten in de fysieke leefomgeving, waarbij de fysieke leefomgeving in het middelpunt staat. ${ }^{19}$ De reikwijdte van de $\mathrm{Ow}$ beperkt zich tot de fysieke leefomgeving én activiteiten die gevolgen hebben of kunnen hebben voor de fysieke leefomgeving. Het wetsvoorstel bevat geen definitie van 'fysieke leefomgeving', noch van de term 'activiteiten'. Wel wordt aangegeven dat het bij 'activiteiten' doorgaans om feitelijke handelingen zal gaan. ${ }^{20}$ De fysieke leefomgeving omvat concreet in ieder geval bouwwerken, infrastructuur, watersystemen, water, bodem, lucht, landschappen, natuur en cultureel erfgoed. Wat verder tot de fysieke leefomgeving behoort

\footnotetext{
15. Dit zijn dan ook de 4 criteria die zijn gebruikt in het onderzoek.

16. MvT, p. 12

17. United Nations World Commission on Environment and Development (1987), Our Common Future, par. 27; Bijlage onder A Ow; MvT, p. 617.

18. MvT, p. 279.

19. MvT, p. 26-27

20. MvT, p. 390-391.
} 
zal per geval moeten worden beoordeeld en is afhankelijk van de heersende maatschappelijke opvattingen. ${ }^{21}$ De wortels van het begrippenpaar 'fysieke leefomgeving' zijn onduidelijk. Wel is duidelijk dat de overheid een zorgplicht heeft betreffende de fysieke leefomgeving. Deze plicht is terug te voeren op art. 21 Grondwet, ${ }^{22}$ dat bepaalt dat de zorg van de overheid gericht is op de bewoonbaarheid van het land en de bescherming en verbetering van het leefmilieu. ${ }^{23}$

\subsection{Omgevingswaarde}

Volgens de $\mathrm{Ow}$ is een omgevingswaarde een norm 'die de gewenste staat of kwaliteit van de fysieke leefomgeving of een onderdeel daarvan als beleidsdoel vastlegt' ${ }^{24}$ Specifieker gesteld bepaalt een omgevingswaarde voor (een onderdeel van) de fysieke leefomgeving de gewenste staat of kwaliteit, de toelaatbare belasting door activiteiten of de toelaatbare concentratie of depositie van stoffen. ${ }^{25}$ Omgevingswaarden zijn normen die objectiveerbaar zijn, doordat ze bijvoorbeeld te meten zijn. Omgevingswaarden zijn gericht tot bestuursorganen en geven gestalte aan de zorgplicht van de overheid voor de fysieke leefomgeving. ${ }^{26}$ Omgevingswaarden kunnen, en in sommige gevallen moeten, kernwaarden zoals veiligheid, gezondheid en de kwaliteit van ecosystemen beschermen. ${ }^{27}$ In een amvb, omgevingsverordening ${ }^{28}$ of omgevingsplan $^{29}$ kunnen omgevingswaarden worden vastgesteld. ${ }^{30}$ Concrete besluiten kunnen ook omgevingswaarden bevatten indien dit is aangegeven door instructieregels, ${ }^{31}$ een instructie ${ }^{32}$ of beoordelingsregels ${ }^{33}$ voor omgevingsvergunningen. ${ }^{34}$ Omgevingswaarden zijn juridisch bindend voor het bestuursorgaan dat ze heeft vastgesteld, maar ook voor burgers en bedrijven indien voorschriften in een omgevingsvergunning ${ }^{35}$ een omgevingswaarde nader uitwerken of omgevingswaarden in algemene regels zijn verwerkt. ${ }^{36}$

Omgevingswaarden lijken op een verbreding van de in het milieurecht bekende 'milieukwaliteitswaarden'. Milieukwaliteitswaarden vormen de uitwerking van milieukwaliteitsnormen of, zoals ze in het milieurecht worden genoemd, milieukwaliteitseisen. ${ }^{37}$ Een milieukwaliteitsnorm vereist een bepaalde kwaliteit van het milieu op een bepaalde tijd en plaats. ${ }^{38}$ Ter illustratie een voorbeeld. Onder bepaalde omstandigheden geldt een zwaveldioxide-emissiegrenswaarde van 200 milligram per Normaal kubieke meter $\left(\mathrm{Nm}^{3}\right)$ voor bepaalde stookinstallaties bij het gebruiken van biomassa als brandstof. ${ }^{39} 200$ milligram per $\mathrm{Nm}^{3}$ is de milieukwali-

31. Het Rijk, via amvb's en de provincies via de omgevingsverordening, kan en moet soms instructieregels opstellen die voorwaarden stellen aan de taak- of bevoegdheidsuitoefening door bestuursorganen van decentrale overheden waaronder bestuursorganen van het eigen overheidsniveau. Instructieregels zijn gericht tot meerdere bestuursorganen en lenen zich voor herhaalde toepassing. Gevallen waarin instructieregels kunnen worden gegeven zijn limitatief opgesomd in het wetsvoorstel (MvT, p. 102-104 en 108). Instructieregels zijn geregeld in afdeling 2.5.1 Ow. Zie ook D. Korsse, De instructieregelbevoegdheid in de Omgevingswet, TBR 2014/10, p. 936-940.

32. Volgens de wetgever is de instructie het aangewezen instrument als 'het stellen van instructieregels wegens het beperkte aantal geadresseerden of de gewenste snelheid van uitvoering minder voor de hand liggend is'. Een instructie is een beschikking en kan een opdracht bevatten tot het (op een bepaalde wijze) nemen of niet nemen van een besluit, het treffen van maatregelen of een feitelijke handeling. Voordat een instructie gegeven wordt, moet er bestuurlijk overleg met het/de betreffende bestuursorgaan/bestuursorganen plaatsvinden. Het kenmerkende verschil met instructieregels is dat herhaaldelijke toepassing niet mogelijk is en het tot één of een beperkt aantal bestuursorganen is gericht (MvT, p. 108-110 en 440). Instructies zijn geregeld in afdeling 2.5.2 Ow.

33. Beoordelingsregels zijn de 'inhoudelijke wettelijke bepalingen over de beoordeling van een vergunningaanvraag' (MvT, p. 172). Zie afdeling 5.1.3 Ow. Zie ook A.G.A. Nijmeijer, Beoordelingsregels in het wetsvoorstel Omgevingswet, TBR 2014/10, p. 926-929.

34. MvT, p. 97-98, 406 en 623-624.

35. De omgevingsvergunning vervangt de omgevingsvergunning van de Wabo. Bij de verlening van een omgevingsvergunning wordt er vooraf getoetst of één of meerdere activiteiten gevolgen hebben voor de fysieke leefomgeving. Centraal staat het begrip (milieubelastende) activiteit en niet meer het begrip inrichting. De omgevingsvergunning biedt flexibiliteit aan het omgevingsplan doordat in concrete gevallen van het omgevingsplan afgeweken kan worden (art. 5.1 lid 1 sub b Ow, vgl. art. 2.1 lid 1 sub c Wabo). Deze mogelijkheid bestaat niet voor de omgevingsverordening of waterschapsverordening (MvT, p. 53-54, 156 en 166-167). Zie afdeling $5.1 \mathrm{Ow}$. Zie ook R. Uylenburg, De omgevingsvergunning in het wetsvoorstel Omgevingswet. Voorlopig beoordeeld, $M$ en R 2014-8.

36. MvT, p. 95-99.

37. Zie bijvoorbeeld titel 5.1 Wet milieubeheer

38. B.A. Beijen (red.), A.A. Freriks, J. Robbe, B.J. Schueler, G.M. van den Broek, A.B. Blomberg, A.M. Keessen \& H.F.M.W. van Rijswick, Hoofdlijnen milieubestuursrecht, Den Haag: Boom Juridische uitgevers 2012, p. 81.

39. Art. 30 lid 2 jo. Bijlage V Richtlijn 2010/75/EU van het Europees parlement en de Raad van 24 november 2010 inzake industriële emissies (geïntegreerde preventie en bestrijding van verontreiniging), PbEU L334/17. 
teitswaarde, die aangeeft hoe hoog de concentratie van een bepaalde stof, in dit geval zwaveldioxide, mag zijn in de lucht. Omgevingswaarden beschrijven, net als milieukwaliteitsnormen, 'de daadwerkelijke kwaliteit die op een bepaalde plaats en op een bepaald moment moet worden bereikt, nagestreefd of in stand worden gehouden'. ${ }^{40}$

\section{Opname van het duurzaamheidsconcept en vertaling in concrete duurzaamheidsdoelen}

Deze paragraaf beschrijft welke rol duurzaamheid in het wetsvoorstel speelt en in hoeverre dit concept is uitgewerkt in concrete doelen.

Duurzaamheid speelt een centrale rol in het wetsvoorstel. Zo vormt de transitie naar een duurzame samenleving een belangrijke aanleiding voor het opstellen van de Ow. Duurzame ontwikkeling eist dat men rekening houdt met de gevolgen die het menselijk handelen heeft op de fysieke leefomgeving, waardoor het noodzakelijk is om opgaven in samenhang te benaderen en te anticiperen op toekomstige ontwikkelingen. ${ }^{41}$ Uit het wetsvoorstel volgt dat de huidige wetgeving nog onvoldoende mogelijkheden biedt om de transitie naar een duurzame samenleving te bevorderen. ${ }^{42}$

De twee primaire doelstellingen van de Ow, zoals genoemd in de introductie, zijn gesteld met het oog op duurzame ontwikkeling. ${ }^{43}$ Het wetsvoorstel bevat verder geen duurzaamheidsdoelstellingen maar biedt bestuursorganen wel de mogelijkheid tot het opstellen ervan. Omgevingswaarden (zie paragraaf 3.3) vormen het vehikel voor de ontwikkeling van duurzaamheidsdoelstellingen. ${ }^{44}$ Een doelstelling, uitgedrukt in meetbare eenheden of andere objectieve grootheden, kan worden opgenomen in een omgevingswaarde. Een bestuursorgaan moet vervolgens monitoren of aan deze omgevingswaarde (lees: doelstelling) is voldaan (zie paragraaf 6). ${ }^{45}$ Naast omgevingswaarden kan een bestuursorgaan ook 'andere doelstellingen voor de fysieke leefomgeving' opstellen, die ook verband houden met de twee primaire doelstellingen. ${ }^{46}$

Andere belangrijke instrumenten voor het vaststellen van duurzaamheidsdoelen zijn de omgevingsvisie (zie paragraaf 5) en programma's. Duurzaamheidsdoelen die

40. MvT, p. 95. Zie ook art. 2.10 Ow.

41. MvT, p. 12

42. MvT, p. 17

43. MvT, p. 20

44. Art. 2.9 lid $1 \mathrm{Ow}$ legt nadrukkelijk een verband tussen omgevingswaarden en de twee primaire doelstellingen van het wetsvoorstel door de formulering 'met het oog op de doelen van de wet'.

45. MvT, p. 24.

46. Zie bijvoorbeeld art. 2.22 lid 1 en 3.4 sub b Ow.

zijn vastgesteld in een omgevingsvisie worden geoperationaliseerd in één of meer programma's. Een program$\mathrm{ma}^{47}$ bevat maatregelen voor 'de ontwikkeling, het gebruik, het beheer, de bescherming of het behoud van de fysieke leefomgeving'. Gemeenten, waterschappen, provincies en het Rijk werken in programma's het beleid voor onderdelen van de fysieke leefomgeving nader uit. Programma's kunnen gericht zijn op een gebied, op een sector of meerdere sectoren, zoals water en natuur, op een omgevingswaarde of op andere doelstellingen betreffende de fysieke leefomgeving. Een bijzondere variant is een 'programma met een programmatische aanpak' (zie paragraaf 4 ). ${ }^{48}$ De programmatische aanpak bewerkstelligt dat in complexe situaties, waarbij het behalen van omgevingswaarden of andere doelstellingen met betrekking tot de fysieke leefomgeving onder druk komen te staan, maar het ontplooien van een activiteit ook van belang is, er toch ruimte wordt gecreëerd om deze activiteiten toe te laten zonder dat het behalen van de omgevingswaarden of andere doelstellingen met betrekking tot de fysieke leefomgeving in gevaar komen. Gedacht kan worden aan een programmatische aanpak voor geur of geluid. ${ }^{49}$

Noties die nauw samenhangen met duurzaamheid spelen ook een belangrijke rol in het wetsvoorstel. Het wetsvoorstel erkent bijvoorbeeld de gevolgen die de uitputting van schaarse natuurlijke bronnen en uitstoot van schadelijke stoffen kan hebben op de fysieke leefomgeving. ${ }^{50}$ Overheden dienen daarom bij het opstellen van regels oog te houden voor het milieu door bijvoorbeeld energiezuinigheid en het zuinig omgaan met grondstoffen te stimuleren. ${ }^{51}$ Een ander voorbeeld, dat weliswaar minder betrekking heeft op de fysieke leefomgeving maar nog steeds verband houdt met duurzaamheid, is het transparantiebeginsel. ${ }^{52}$ Volgens de Ow eist de samenleving namelijk transparante besluitvormingsprocedures, hetgeen in het huidige omgevingsrecht volgens de opstellers nog te weinig gewaarborgd is. ${ }^{53}$ Transparantie komt in het wetsvoorstel onder andere terug in de eis dat de belangenafweging van bestuursorganen transparant moet geschieden, ${ }^{54}$ dat besluitvormingsprocedures transparanter moeten worden, ${ }^{55}$ dat toezichthouders transparantie dienen te betrachten ten opzichte van beleidsmakers ${ }^{56}$ en in het feit dat de invoering van ver-

47.$$
48 .
$$

onderne link tussen transparantie en maatschappelijk verantwoord ondernemen (MVO), een thema dat veel raakvlakken heeft met duurSocial Responsibility and Transparency: how could we amend Dutch law to improve transparency with regard to Dutch multinational companies?, International and Comparative Corporate Law Journal 2013-10/2, p. 28-43.

53. MvT, p. 14.

54. MvT, p. 39.

55. MvT, p. 208.

56. MvT, p. 48-49. 
schillende omgevingsinstrumenten, zoals de omgevingsvisie en programma's, een grotere transparantie als effect sorteren. ${ }^{57}$

Opvallend is dat de wetgever erkent dat de fysieke leefomgeving intrinsieke waarde heeft of kan hebben. Als voorbeeld van een intrinsieke waarde van de fysieke leefomgeving noemt het wetsvoorstel biodiversiteit. Deze erkenning van intrinsieke waarde aan niet-menselijk leven, in dit geval de fysieke leefomgeving, vindt bijval bij bepaalde duurzaamheidstheorieën. ${ }^{58}$ Een aantal filosofen zoals A. Naess en G. Session heeft een aantal principes vastgelegd die samen de 'deep ecology theory' constitueren. Volgens deze theorie heeft het niet-menselijk leven een eigen intrinsieke waarde, onafhankelijk van de waarde die er aan toe wordt gekend door de mens. Overigens lijkt de houding van de wetgever ten opzichte van deze theorie ambivalent. De wetgever stelt zowel dat de fysieke leefomgeving van zichzelf intrinsieke waarde heeft als dat de maatschappij intrinsieke waarde aan de fysieke leefomgeving kan toekennen. ${ }^{59}$ Het wetsvoorstel geeft overigens niet aan of de verschillende in de $\mathrm{Ow}$ genoemde onderdelen van de fysieke leefomgeving, zoals het water of de natuur, een intrinsieke waarde hebben en verbindt bovendien geen gevolgen aan de toekenning van intrinsieke waarde aan (een bepaald onderdeel van) de fysieke leefomgeving.

Verscheidene beginselen van milieurecht die gerelateerd zijn aan duurzaamheid dienen als uitgangspunt bij het opstellen van de Ow. Deze vloeien rechtstreeks voort uit het Europese recht. Gedacht kan worden aan de volgende beginselen: (i) het voorzorgsbeginsel; ${ }^{60}$ (ii) het beginsel van preventief handelen; ${ }^{61}$ (iii) het bronbeginsel; ${ }^{62}$ (iv) het 'vervuiler betaalt'-beginsel; (v) het beginsel van geen achteruitgang (standstill-beginsel); (vi) het nabijheidsbeginsel; ${ }^{63}$ en (vii) het beginsel dat de beste beschikbare technieken worden ingezet. ${ }^{64}$ Een belangrijke kanttekening die bij de toepassing van deze beginselen gemaakt moet worden is dat de Nederlandse wetgever op belangrijke onderdelen van het omgevingsrecht niet verder gaat dan wat Europese richtlijnen voorschrijven. ${ }^{65}$ Dit betekent dat een strengere toepassing van één of meerdere van de bovengenoemde milieubeginselen die verwerkt zijn in een Europese richtlijn in beginsel rechtens niet geëist kan worden.

57. MvT, p. 134

58. P. Singer, Practical Ethics, New York: Cambridge University Press 2011, p. 251

59. MvT, p. 63 en 392

60. Het voorzorgsbeginsel houdt in dat er in het besluitvormingsproces rekening wordt gehouden met mogelijke milieugevolgen, ook indien er een gebrek aan wetenschappelijk bewijs bestaat voor te verwachten milieuschade (Beijen (red.) e.a. 2012, p. 37).

61. Het preventiebeginsel schrijft voor dat beschermingsmaatregelen voor het milieu in een zo vroeg mogelijk stadium worden getroffen (Beijen (red.) e.a. 2012, p. 23).

62. Volgens het bronbeginsel moet milieuvervuiling bij de bron worden aangepakt (Beijen (red.) e.a. 2012, p. 24).

63. Het nabijheidsbeginsel bepaalt bijvoorbeeld dat afval wordt vervoerd naar een nabijgelegen installatie zodat het aldaar verwerkt kan worden.

64. MvT, p. 37

65. MvT, p. 35

\section{Integratie en coördinatie}

Duurzaamheid vraagt om een afweging van verschillende belangen, zoals economische, ecologische en sociale belangen. Daarom is het van belang dat wetgeving een integraal karakter heeft zodat belangen integraal afgewogen kunnen worden. De noodzaak van coördinatie bij het betrekken van verschillende belangen is ook van belang. Deze paragraaf beschrijft hoe aan de eis van integratie en coördinatie wordt voldaan.

Integratie en coördinatie vormen een belangrijk onderdeel van de $\mathrm{Ow}$ en beogen duurzaam handelen te bevorderen. ${ }^{66}$ De wetgever spreekt niet voor niets van een samenhangende zorg voor de fysieke leefomgeving. Besluiten dienen zo veel mogelijk integraal genomen te worden teneinde alle achterliggende belangen die betrekking hebben op fysieke leefomgeving mee te wegen. Een voorbeeld vormen de twee primaire doelstellingen van het wetsvoorstel (zie paragraaf 1). Deze doelstellingen moeten in samenhang benaderd worden evenals de achter de doelstellingen liggende belangen. Dit betekent dat de onderdelen van de fysieke leefomgeving (zie paragraaf 3.2), zoals natuur en infrastructuur, in samenhang moeten worden benaderd. ${ }^{67}$ Integraliteit wordt ook benadrukt als het gaat om de aanpak van verschillende milieuopgaven die zich op meerdere bestuurlijke niveaus manifesteren, zoals bij de aanpak van luchtverontreiniging of waterverontreiniging. ${ }^{68}$

Coördinatie is een randvoorwaarde voor het slagen van de Ow. Taken van de verschillende overheden ${ }^{69}$ kunnen alleen succesvol worden uitgevoerd als er coördinatie van beleid, besluiten en feitelijke handelingen plaatsvindt. De belangrijkere rol van algemene regels in de $\mathrm{Ow}$ en, indien algemene regels niet van toepassing zijn, het zo veel mogelijk naar buiten toe treden als één overheid bij de verlening van vergunningen ('één loket, één bevoegd gezag en één besluit') onderstreept het belang van coördinatie. ${ }^{70}$ De overheid treedt met één gezicht naar buiten, ook als er meerdere overheden betrokken zijn bij het nemen van een besluit. Overheden dienen daarom ook achter de schermen handelingen op elkaar af te stemmen. ${ }^{71}$

Een effectieve coördinatie vindt, in tegenstelling tot het huidige omgevingsrecht, plaats door beleid en normstelling te scheiden. Beleidsdocumenten binden voortaan alleen het bestuursorgaan dat het document heeft vastgesteld. In het huidige omgevingsrecht is dat anders. Een provinciale structuurvisie bijvoorbeeld bindt in

66. MvT, p. 282

67. MvT, p. 31 en 62

68. MvT, p. 74

69. De gemeente is de hoofdrolspeler bij de ontwikkeling en het beheer van de fysieke leefomgeving en waterschappen spelen een belangrijke rol als het gaat om watersystemen. Provincies en het Rijk zijn actief in de fysieke leefomgeving, maar krijgen geen hoofdrol toebedeeld in de Ow (MvT, p. 42-43). Zie ook art. $2.3 \mathrm{Ow}$

70. MvT, p. 31.

71. MvT, p. 32 
zekere mate ook de gemeentelijke overheid in die mate dat de gemeentelijke overheid er rekening mee dient te houden bij de vaststelling van gemeentelijk beleid. ${ }^{72}$ Dit verandert met de komst van de Ow. Binding van andere overheden is in het nieuwe omgevingsrechtelijk regime alleen nog maar mogelijk door daartoe rechtsregels of beschikkingen vast te stellen. ${ }^{73}$

Verschillende instrumenten (zie figuur 1) bewerkstelligen een zekere samenhang in het toekomstige omgevingsrecht. Een voorbeeld is de omgevingsvisie. ${ }^{74}$ De wetgever stelt vast dat de samenhang die een omgevingsvisie biedt essentieel is voor de duurzame ontwikkeling van de fysieke leefomgeving. ${ }^{75}$ De omgevingsvisie is een langetermijnvisie van een bestuursorgaan met betrekking tot de ontwikkelingen binnen de fysieke leefomgeving binnen het gebied dat onder zijn competentie valt en bevat beleidsdoelen voor de kwaliteit van de fysieke leefomgeving inclusief een beschrijving hoe deze doelen gerealiseerd zullen worden. De omgevingsvisie is een beleidsdocument en bindt alleen het bestuursorgaan dat het document heeft vastgesteld. Voor het Rijk en de provincies is het opstellen van een omgevingsvisie verplicht, voor gemeenten facultatief. Waterschappen kunnen geen omgevingsvisie opstellen. De omgevingsvisie beschrijft de rol van het bestuursorgaan dat de omgevingsvisie vaststelt bij de realisatie van zijn doelen en de rol van andere partijen. Bij beleidsuitvoering kunnen deze andere partijen met de omgevingsvisie rekening houden, waardoor een zekere mate van samenhang wordt gecreëerd. Bovendien betrekt het bestuursorgaan alle onderdelen van de fysieke leefomgeving in de omgevingsvisie ter versterking van de samenhang. ${ }^{76}$

Andere instrumenten die een zekere samenhang beogen zijn bijvoorbeeld de omgevingsvergunning en het projectbesluit. De omgevingsvergunning integreert een zevental bestaande vergunningstelsels ${ }^{77}$ en het projectbesluit biedt de mogelijkheid om alle toestemmingen die nodig zijn voor activiteiten met één besluit te verlenen. Het projectbesluit kan daarom de plaats innemen van

Zie bijv. ABRvS 27 oktober 2010, AB 2010/335, m.nt. De Gier (Boxmeer).

73. MvT, p. 44-45

74. Afdeling $3.1 \mathrm{Ow}$.

75. MvT, p. 117

76. De omgevingsvisie vervangt instrumenten met een soortgelijk effect, zoals de structuurvisies en strategische delen van nationale waterplannen (MvT, p. 51 en 114).

77. MvT, p. 189. Zie ook S. Hillegers \& T.E.P.A. Lam, (G)een integrale afweging op vergunningniveau, M en R 2014-8. omgevingsvergunningen voor activiteiten die betrekking hebben op het project. $^{78}$

Tot slot integreren het omgevingsplan van de gemeente, de waterschapsverordening ${ }^{79}$ van de waterschappen en de omgevingsverordening van de provincie het huidige omgevingsrecht. Deze verordeningen en plannen vormen één gebiedsdekkende regeling waaronder alle regels met betrekking tot de fysieke leefomgeving gebracht kunnen worden. Dit in tegenstelling tot het huidige omgevingsrecht waarin het mogelijk is verschillende bestemmingsplannen voor één gebied vast te stellen evenals verordeningen vast te stellen op specifieke terreinen, zoals een kapverordening of monumentenverordening. De wetgever hoopt deze wildgroei van verschillende regels te voorkomen door alles onder te brengen in één regeling. ${ }^{80}$ Deze integratie zal leiden tot minder regels, althans dat is de verwachting. ${ }^{81}$

Naast integratie middels instrumenten voorziet het wetsvoorstel in algemene samenwerkings- en coördinatiebepalingen. Het wetsvoorstel bepaalt dat bestuursorganen rekening moeten houden met de taken en bevoegdheden van andere bestuursorganen en biedt de mogelijkheid om gezamenlijk taken en bevoegdheden uit te oefenen. ${ }^{82}$ De taken en bevoegdheden mogen niet overgedragen worden, maar mogen wel worden verdeeld onder de bestuursorganen van het Rijk, provincie en de gemeente.$^{83}$ Een meer specifieke variant van afstemming en samenwerking zal te vinden zijn in hoofdstuk 18 van de Ow. ${ }^{84}$ Dit hoofdstuk voorziet in de coördinatie en integratie van het omgevingsrechtelijke toezichts- en handhavingsregime ${ }^{85}$ Intensievere samenwerking en het leveren van 'voldoende kwaliteit' door de verschillende

78. Een waterschap, provincie of het Rijk kan een projectbesluit nemen voor ontwikkelingen in de fysieke leefomgeving. Het projectbesluit kan ter realisering van het project tevens omgevingsplannen wijzigen. Deze mogelijkheid lijkt niet te bestaan voor de omgevingsverordening of waterschapsverordening (zie art. $5.50 \mathrm{Ow}$ ). Het projectbesluit vervangt onder andere het inpassingsplan uit de Wro en het projectplan uit de Waterwet. Het verschil tussen het projectbesluit en de omgevingsvergunning is dat het projectbesluit door de overheid ter behartiging van het publiek belang wordt genomen. Bij een omgevingsvergunning wordt er beslist naar aanleiding van een verzoek van een initiatiefnemer (MvT, p. 54, 156 en 176). Zie afdeling 5.2 Ow. Zie ook T.E.P.A. Lam, De omgevingsvergunning en het projectbesluit, TBR 2014/10, p. 950-956.

79. De waterschapsverordening is een verordening waar het algemeen bestuur van het waterschap regels over de fysieke leefomgeving in op kan, of soms moet, nemen. Het algemeen bestuur van het waterschap stelt één waterschapsverordening vast voor het watersysteem, en soms ook de wegen, binnen het beheergebied van het waterschap (art. 2.5 Ow; MvT, p. 402). Welke regels de waterschapsverordening moet bevatten staat onder andere in de $\mathrm{Ow}$ en Waterschapswet (MvT, p. 87).

80. MvT, p. 52

81. MvT, p. 80.

82. Art. $2.2 \mathrm{OW}$.

83. De genoemde artikelen laten onverlet dat waterschappen een eigen taken- en bevoegdhedenpakket hebben (MvT, p. 397-398).

84. Hiervoor is afdeling 18.3 Ow gereserveerd.

85. Zie over handhaving in de Omgevingswet F.C.M.A. Michiels, Handhaving in de Omgevingswet, TBR 2014/10, p. 957-964. 
uitvoeringsoverheden zijn in dit kader zwaarwegende factoren. $^{86}$

Een opvallend fenomeen in het omgevingsrecht dat onder de noemer van integratie en coördinatie kan worden gebracht is wat de wetgever 'co-actorschap' noemt. Wat opvalt, is dat men tevergeefs in de Ow zal zoeken naar deze term. Niettemin komt de term meermalen terug in de memorie van toelichting, zonder dat het wordt gedefinieerd. 'Co-actorschap' behelst hoogstwaarschijnlijk een integrale aanpak onder gezamenlijke verantwoordelijkheid van meerdere bestuurlijke niveaus (het Rijk, de provincies, de gemeenten en de waterschappen) met het doel een effectieve en efficiënte bescherming en ontwikkeling van de fysieke leefomgeving. ${ }^{87}$ Misschien dat art. $2.2 \mathrm{Ow}$ nog wel het dichtste in de buurt komt bij de intentie van de opstellers van de Ow. De wettelijke verankering van het gezamenlijk kunnen uitoefenen van taken en bevoegdheden door verschillende bestuursorganen, bijvoorbeeld door gezamenlijk een besluit te nemen, is gebaseerd op 'co-actorschap'. ${ }^{88}$

\section{Monitoring en evaluatie}

Het opstellen van doelen en afwegen van verschillende belangen in het kader van duurzaamheid heeft weinig zin als de voortgang die er mee wordt geboekt niet wordt gemonitord en geëvalueerd. ${ }^{89}$ Door monitoring en evaluatie is het mogelijk om doelen aan te passen en verbetering te realiseren. Deze paragraaf beschrijft hoe de Ow tegemoet komt aan deze eis.

Een belangrijke rol is weggelegd voor monitoring in hoofdstuk 20 van het wetsvoorstel. De Ow volgt een bepaalde beleidscyclus (zie figuur 1), waarin monitoring is opgenomen. Deze beleidscyclus waarborgt een zekere continuiteit van de kwaliteit van het omgevingsrecht door een cyclische aanpak. Overigens is de cyclische aanpak niet geheel juridisch geborgd; het is aan een bestuursorgaan om de volgende stap in de cyclus te zetten. ${ }^{90}$

In de Ow geldt een monitoringsplicht voor iedere vastgestelde omgevingswaarde. ${ }^{91}$ Uit monitoring moet blijken of aan gestelde omgevingswaarden is voldaan en of de staat of kwaliteit van de fysieke leefomgeving niet is verslechterd, de belasting door activiteiten niet is toegenomen of de concentratie of depositie van stoffen in de fysieke leefomgeving niet is verhoogd. Input van deze

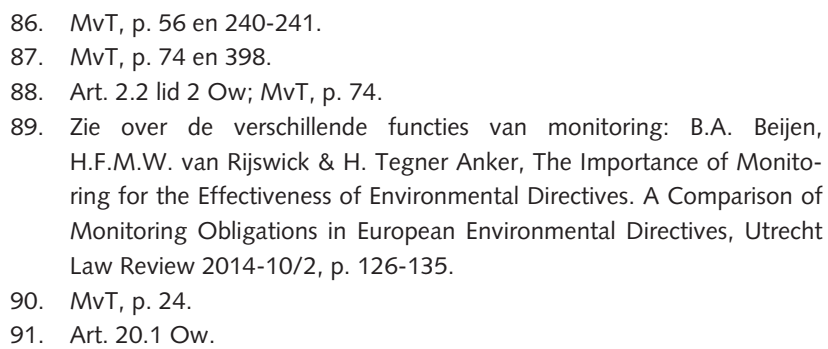

monitoringsrondes kan gebruikt worden voor verdere beleidsontwikkeling. Als bijvoorbeeld een bestuursorgaan vaststelt dat een omgevingswaarde niet zal worden gehaald, dan moet het bestuursorgaan een programma vaststellen. ${ }^{92}$ Maatregelen in deze programma's moeten verzekeren dat aan omgevingswaarden blijvend wordt voldaan. Het wetsvoorstel 'verzekert' op haar beurt dat de maatregelen in programma's worden uitgevoerd, zie bijvoorbeeld art. $3.17 \mathrm{Ow}$ dat een uitvoeringsplicht bevat. Deze uitvoeringsplicht is echter afhankelijk van de instemming van bestuursorganen. Indien alsnog niet voldaan wordt aan een omgevingswaarde, dan moet het programma worden aangepast, op zo een wijze dat binnen een passende termijn wel aan de omgevingswaarde wordt voldaan. ${ }^{93}$ Het doel van het programma mag zelfs worden aangepast zolang dit er maar toe leidt dat aan de omgevingswaarde is voldaan. ${ }^{94}$ Indien het programma niet wordt aangepast of de maatregelen uit het (aangepaste) programma niet worden uitgevoerd, dan kan het vertegenwoordigende orgaan het uitvoerende orgaan hierop aanspreken. Indien er sprake is van een verplicht programma of een programma met een programmatische aanpak, dan kan in het kader van interbestuurlijk toezicht tevens indeplaatsstelling door een ander bestuursorgaan plaatsvinden. ${ }^{95}$

Regels omtrent informatieverstrekking aan het publiek kunnen in een amvb worden geregeld. Deze amvb kan regels bevatten over het ter beschikking stellen van de resultaten van monitoring aan het publiek en het ter beschikking stellen van informatie als niet voldaan wordt of dreigt te worden voldaan aan een omgevingswaarde. ${ }^{96}$ Het wetsvoorstel maakt het tevens mogelijk een register in te stellen met daarin de resultaten van monitoring. Een aantal registers moet verplicht opgesteld worden, zoals een landelijk register met gegevens over de uitstoot en overbrenging van verontreinigende stoffen. Tot slot dient het bestuursorgaan dat verantwoordelijk is voor de monitoring te rapporteren over de resultaten van het monitoren van omgevingswaarden en te rapporteren over de voortgang, uitvoering en het doelbereik van een programma met een programmatische aanpak. ${ }^{97}$ In een aantal gevallen moet het bevoegd gezag de resultaten van monitoring in kaarten vastleggen. ${ }^{98}$

De laatste artikelen van het monitoringhoofdstuk van de Ow betreffen de evaluatiefase. Deze artikelen bepalen dat er wetenschappelijk onderzoek moet plaatsvinden naar de ontwikkeling van de kwaliteit van bepaalde onderdelen van de fysieke leefomgeving, de ontwikkeling en staat van cultureel erfgoed en de doeltreffendheid en de effecten van de omgevingswaarden voor de

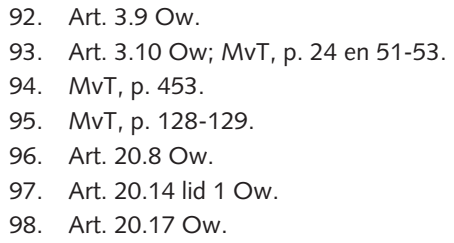




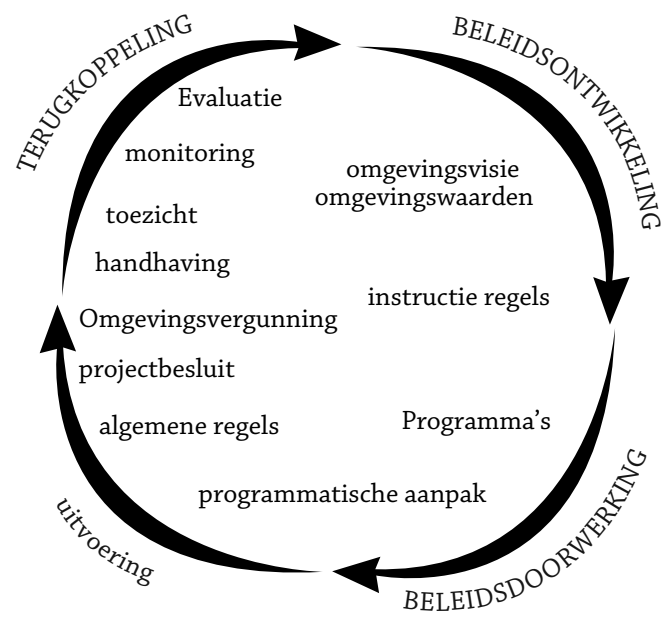

* MvT, p. 22 (bewerkt).

veiligheid van primaire waterkeringen. Het onderzoek naar de omgevingswaarden voor de veiligheid van primaire waterkeringen vindt elke twaalf jaar plaats, de overige twee onderzoeken vinden ten minste eenmaal per vier jaar plaats. ${ }^{99}$

Volgens de wetgever bestaan er grote raakvlakken tussen de monitoringsronde uit de beleidscyclus en de evaluatie die plaatsvindt in het kader van een milieueffectbeoordeling (m.e.r.). Als sluitstuk van de m.e.r. geldt het beoordelen van de werkelijke milieugevolgen, waardoor bijsturing van activiteiten mogelijk wordt. Aangezien monitoring van omgevingswaarden al plaatsvindt op grond van het monitoringshoofdstuk van de $\mathrm{Ow}$, worden omgevingswaarden in het kader van de m.e.r. niet geëvalueerd. Om die reden sluit de m.e.r.-evaluatie niet geheel aan op de beleidscyclus. De m.e.r.-evaluatie zal verder uitgewerkt worden in een amvb. ${ }^{100}$

\section{Publieke participatie}

Om draagvlak te verkrijgen voor besluiten is het van belang om het publiek te betrekken bij de besluitvorming. Participatie van het publiek kan tevens nuttige inzichten opleveren. Uit sociaalwetenschappelijk onderzoek blijkt dat als burgers in een vroeg stadium bij het besluitvormingsproces worden betrokken en effectieve invloed mogen uitoefenen, de kwaliteit van het besluit verhoogd wordt en het verzet tegen het besluit wordt verminderd. ${ }^{101}$ In deze paragraaf wordt bezien hoe het wetsvoorstel publieke participatie organiseert.

99. Art. 20.18 en 20.19 Ow

100. MvT, p. 224

101. C. de Brauw, M. van Amstel-van Saane \& Tj. de Cock Buning, Burgerparticipatie in het omgevingsrecht. Zet de regulering - nu en in de Omgevingswet - aan tot het instellen van bezwaar en beroep?, TO 2013, nr. 4, p. 143-153. Zie ook A.M. Keessen, A.J.F. van Daalen \& M.W. van Buuren, Participatie in watermanagement. Goed voorbeeld doet volgen?, NJB 2014-30, p. 2117-2124.
Analoog aan de ontwikkelingen in het sociale domein, verwacht de wetgever in het omgevingsrecht een cultuuromslag waarbij er meer van burgers wordt verwacht. ${ }^{102}$ Ook bedrijven hebben een verantwoordelijkheid. Bedrijven moeten namelijk vroegtijdige participatie van de omgeving organiseren en op deze manier bijdragen aan de kwaliteit van de fysieke leefomgeving. ${ }^{103}$

De eigen verantwoordelijkheid die burgers en bedrijven dragen komt met name tot uitdrukking in de zorgplicht voor de fysieke leefomgeving. Een ieder die redelijkerwijs kan vermoeden dat zijn activiteit nadelige gevolgen kan hebben voor de fysieke leefomgeving moet die gevolgen voorkomen, beperken of ongedaan maken. In sommige gevallen moet de activiteit zelfs beëindigd worden. ${ }^{104}$ De zorgplichtbepalingen uit de Ow vervangen verschillende zorgplichtbepalingen uit bijvoorbeeld de Waterwet, ${ }^{105}$ Wet milieubeheer ${ }^{106}$ en de Woningwet. ${ }^{107}$ De zorgplicht dient onder andere ${ }^{108}$ burgers bewust te maken van hun eigen verantwoordelijkheid. De wetgever spreekt dan ook van 'burgerplichten'. Bedrijven kunnen invulling geven aan hun zorgplicht door maatschappelijk verantwoord te ondernemen. ${ }^{109}$

Hoewel niet duidelijk is of de nadruk op eigen verantwoordelijkheid publieke participatie zal stimuleren of juist zal ontmoedigen, is het wel duidelijk dat de $\mathrm{Ow}$ publieke participatie stimuleert als het gaat over de controle door 'derden'. Derden moeten verantwoordelijke

102. MvT, p. 24-25.

103. MvT, p. 41

104. Art. 1.6 en $1.7 \mathrm{Ow}$

105. Art. 6.8 Waterwet.

106. Art. 1.1a Wet milieubeheer.

107. Art. 1a Woningwet.

108. De zorgplicht heeft bijvoorbeeld ook een vangnetfunctie voor die gevallen die niet door de wetgever zijn voorzien, maar wel aperte strijd met de zorgplicht tot gevolg hebben. Doordat de zorgplicht open normen bevat en een brede reikwijdte is strafrechtelijke handhaving overigens niet mogelijk. Dit is wel mogelijk voor specifieke zorgplichten die de algemene zorgplicht preciseren en nader geregeld worden in amvb's (MvT, p. 70-71).

109. MvT, p. 66-71. 
bestuursorganen kunnen aanspreken op het niet behalen van milieuwaarden, kwaliteiten of de uitvoering van beleid en worden gestimuleerd hun controletaak uit te oefenen. De beschikbaarheid van gegevens alsmede vergaarde informatie uit monitoringsrondes moet deze controletaak vergemakkelijken. ${ }^{110}$

In 2008 propageerde de Commissie Elverding de 'sneller en beter'-aanpak. ${ }^{111}$ Deze aanpak vormt een ander voorbeeld van publieke participatie en kan een duurzaamheidsbevorderend effect sorteren. ${ }^{112}$ De 'sneller en beter'-aanpak stimuleert de participatie van derden, door derden al in de verkenningsfase actief te betrekken bij probleemanalyses, bij de formulering van ambities en bij het ontwikkelen van oplossingen of alternatieven. ${ }^{113}$ De wetgever integreert deze aanpak in het wetsvoorstel door derden te betrekken bij de ontwikkeling van beleid en besluitvorming. ${ }^{114}$ Het doel van het betrekken van andere partijen bij de voorbereiding van besluiten of plannen is het vergaren van nieuwe kennis en ideeën en het in kaart brengen van belangen. Door andere partijen te betrekken bij het besluitvormingsproces, hoopt de wetgever het vertrouwen in de rechtvaardigheid van het besluit te vergroten en dientengevolge de vergroting van het vertrouwen van burgers in de overheid. De wetgever organiseert deze vormen van participatie naast de formele vormen van participatie middels inspraak. ${ }^{115}$ Een voorbeeld waar deze 'sneller en beter'-aanpak wordt toegepast is het projectbesluit ${ }^{116}$ en het gemeentelijk project van publiek belang. ${ }^{117}$

Een aantal formele vormen van participatie is geregeld in afdeling $16.3 \mathrm{Ow}$. Deze afdeling verklaart de uniforme openbare voorbereidingsprocedure (uov) van de Awb van toepassing op de totstandkomingsprocedure van onder andere de voorbereiding van een omgevingsvisie, de voorbereiding van verplichte programma's en programma's met een programmatische aanpak, ${ }^{118} \mathrm{de}$ voorbereiding van het omgevingsplan, de voorbereiding van de waterschapsverordening en de voorbereiding van de omgevingsverordening. ${ }^{119}$ In tegenstelling tot de uov van de Awb kan doorgaans een ieder een zienswijze indienen bij de genoemde totstandkomingsprocedures. ${ }^{120}$ De wetgever geeft verder nadrukkelijk aan dat het volgen van de wettelijke procedure niet in alle gevallen

110. MvT, p. 23.

111. Zie ook motie-Samsom (Kamerstukken II 2009/10, 32 127, nr. 105).

112. MvT, p. 282.

113. Elverding e.a., Sneller en beter. Advies Commissie Versnelling Besluitvorming Infrastructurele Projecten (2008), p. 14-15.

114. MvT, p. 24

115. MvT, p. 47

116. MvT, p. 176.

117. Art. $5.53 \mathrm{OW}$

118. MvT, p. 219. Onverplichte programma's kunnen ook onder de uov vallen door deze van toepassing te verklaren (art. 3:10 lid 1 jo. art. 3:1 lid $2 \mathrm{Awb}$ ).

119. Art. $16.25,16.26,16.28$ en 16.30 Ow.

120. Art. 3:15 lid 2 Awb jo. art. 16.22 lid 1 Ow. Art. 16.22 lid 2 Ow biedt een uitzondering op deze regel voor gedoogbeschikkingen en art. 16.29 Ow bepaalt dat geen zienswijze kan worden ingediend voor een omgevingsvergunning voor een afwijkactiviteit die in het omgevingsplan moet worden omgezet. voldoende zal zijn. Het is de verantwoordelijkheid van het bestuursorgaan om op eigen initiatief, vanuit het oogpunt van democratische legitimatie, een passend moment te bepalen om eventuele aanvullende activiteiten te organiseren waarbij inbreng geleverd kan worden. De Code Maatschappelijke Participatie kan volgens de wetgever bij de voorbereiding van besluiten en het betrekken van de omgeving als leidraad dienen. ${ }^{121}$

Participatie met betrekking tot het opstellen van een milieueffectrapport (MER) is niet geregeld in afdeling 16.3 Ow. De participatie van derden is wel zo veel mogelijk gestroomlijnd met de participatievormen zoals geregeld in afdeling $16.3 \mathrm{Ow}$. Voor bepaalde plannen of programma's en nader bij amvb te bepalen besluiten waarvoor een MER moet worden opgesteld geldt namelijk ook de uov. ${ }^{122}$ Dit geldt in ieder geval voor bepaalde omgevingsvisies, programma's, omgevingsplannen ${ }^{123}$ en voorkeursbeslissingen. ${ }^{124}$ Het van toepassing verklaren van de uov leidt er toe dat de mogelijkheid tot het indienen van zienswijzen op het voornemen een MER op te stellen komt te vervallen, omdat de aparte kennisgeving van het voornemen een MER op te stellen niet in het wetsvoorstel is opgenomen. Volgens de wetgever is juridische borging niet noodzakelijk en hangt participatie in grote mate af van de professionaliteit van de partijen. ${ }^{125}$

Speciale aandacht verdienen de projectprocedure naar aanleiding van het projectbesluit en het grotendeels gelijkvormige gemeentelijk project van publiek belang. Het bestuursorgaan moet in deze procedure kennis geven van het voornemen om een verkenning uit te voeren voor een opgave betreffende de fysieke leefomgeving waar het bestuursorgaan voor staat. Bovendien dient het bestuursorgaan een ieder de mogelijkheid te bieden mogelijke alternatieve oplossingen aan te dragen voor deze opgave. Dit kan gevolgd worden door een voorkeursbeslissing waarin wordt nagegaan of het wenselijk is een project te starten of niet. De Ow bepaalt dat het te nemen projectbesluit aangeeft hoe burgers, bedrijven, maatschappelijke organisaties en bestuursorganen bij de voorbereiding zijn betrokken en wat de resultaten zijn van de uitgevoerde verkenning. ${ }^{126}$ Als een maatschappelijk initiatief is ingebracht door een initiatiefnemer maar niet geheel of gedeeltelijk is overgenomen, dan is het mogelijk om een adviesgroep in te stellen om binnen een redelijke termijn een advies uit te brengen over de haalbaarheid van het maatschappelijk initiatief. Deze adviesgroep kan bestaan uit experts uit het eigen netwerk van de initiatiefnemer. ${ }^{127}$ De installatie van een dergelijke

121. MvT, p. 217-218.

122. Art. 16.38 lid 1 jo. 16.34 lid 1 jo. 16.41 lid 1 Ow en art. 16.48 lid 1 en 16.41 lid 1 Ow.

123. Zie voor een praktijkvoorbeeld van een omgevingsplan: A. Snijders, C.S. Cuppen, S.A. Renders \& K.B.J. Steenbakkers, Het maken van een omgevingsplan, deel 1, Gst. 2014-70, p. 314-319; A. Snijders, C.S. Cuppen, S.A. Renders \& K.B.J. Steenbakkers, Het maken van een omgevingsplan, deel 2, Gst. 2014-77.

124. Art. 16.32 lid 2 Ow

125. MvT, p. 223-224.

126. Afdeling $5.2 \mathrm{OW}$.

127. MvT, p. 218. 
adviesgroep vormt in zekere mate een waarborg dat participanten daadwerkelijk worden gehoord.

Hoewel de projectprocedure een aparte procedure is, is voor de voorbereiding van een projectbesluit afdeling 3.4 Awb van toepassing verklaard. ${ }^{128}$ Dit staat in contrast met de voorbereidingsprocedures bij programma's, omgevingsplannen, omgevingsverordeningen en waterschapsverordeningen, welke voorbereidingsprocedures niet wettelijk zijn vastgelegd. Het gaat dus om de voorbereidingsprocedure van afdeling 3.4 Awb. Het bevoegd gezag mag, voordat de formele uov van start gaat, bij de vaststelling van programma's, omgevingsplannen en bij omgevings- en waterschapsverordeningen zelf de procedure vormgeven. ${ }^{129}$ Of participatie gestimuleerd wordt, hangt dus af van de invulling van deze procedures door het bestuursorgaan.

Voor de voorbereiding van een beslissing op de aanvraag van een omgevingsvergunning gelden twee procedures. Hoofdregel is de toepassing van de reguliere procedure $^{130}$ die sterke verwantschap toont met de reguliere procedure van de Wabo en gestoeld is op de reguliere procedure van de Awb. Inspraakmogelijkheden kunnen volgens de wetgever worden ingebouwd door het bevoegd gezag. Het bevoegd gezag zou het mogelijk kunnen maken dat zienswijzen worden ingediend naar aanleiding van een aanvraag of ontwerpbesluit. Het is tevens mogelijk om voorafgaand aan de formele aanvraag, informeel de conceptaanvraag te bespreken met de indiener en eventuele belanghebbenden. Volgens de wetgever is hiervoor geen wettelijke regeling nodig. ${ }^{131}$ In het geval de aanvraag van een omgevingsvergunning geheel of gedeeltelijk betrekking heeft op een bij amvb aangewezen activiteit wordt afdeling $3.4 \mathrm{Awb}$ toegepast op de voorbereiding van een beslissing op de anvraag van een omgevingsvergunning. ${ }^{132}$ Toepassing van afdeling 3.4 Awb betreft onder meer activiteiten met belangrijke gevolgen voor de fysieke leefomgeving. ${ }^{133}$ In bijzondere gevallen kan het bevoegd gezag er echter voor kiezen om afdeling 3.4 Awb buiten toepassing te verklaren, bijvoorbeeld als nationale veiligheidsbelangen dat vereisen. ${ }^{134}$

\section{Conclusie en aanbevelingen}

Zoals in dit artikel uiteen is gezet, besteedt het wetsvoorstel veel aandacht aan het duurzaamheidsconcept en de 'vier criteria' waar wij gebruik van hebben gemaakt, om het begrip duurzaamheid nader in te vullen. Duurzame ontwikkeling biedt het fundament waarop de twee belangrijkste doelen van de $\mathrm{Ow}$ zijn gebouwd. De ver-

\footnotetext{
128. Art. 16.69 sub a Ow.

129. MvT, p. 235.

130. Afdeling 16.5.2 Ow

131. MvT, p. 226

132. Afdeling 16.5.3 Ow

133. MvT, p. 569

134. Art. $16.66 \mathrm{Ow}$
}

dere uitwerking van het duurzaamheidsconcept in omgevingswaarden biedt de mogelijkheid om het duurzaamheidsconcept nader te concretiseren en te operationaliseren. Het wetsvoorstel focust op integratie en coördinatie, ook met betrekking tot de verschillende onderdelen van de fysieke leefomgeving. In principe bevorderen deze integratie en coördinatie duurzaamheid, omdat belangen integraal afgewogen kunnen worden. Anders dan in de huidige sectorale wetgeving, waar gelet op het specialiteitsbeginsel bevoegdheden die de wetten toekennen alleen kunnen worden gebruikt met het oog op het doel waarvoor die bevoegdheden zijn verleend, bieden de instrumenten uit de $\mathrm{Ow}$ dus meer ruimte om belangen integraal af te (kunnen) wegen. De verankering van het monitoren van omgevingswaarden biedt in potentie de mogelijkheid om de voortgang op het gebied van duurzaamheid met enige regelmaat te controleren. Het wetsvoorstel zorgt er tevens voor dat onderdelen van de fysieke leefomgeving op wetenschappelijk verantwoorde wijze geëvalueerd worden. Verder stimuleert het wetsvoorstel publieke participatie door de toepassing van de 'sneller en beter'-aanpak en moedigt de wetgever informele participatievormen aan door ook buiten de kaders van de $\mathrm{Ow}$ te kijken. Al met al lijkt op het eerste gezicht in voldoende mate te zijn voldaan aan de vier criteria zoals genoemd in paragraaf 2 en is duurzaamheid in voldoende mate en soms in hoge mate gewaarborgd.

Deze conclusie is echter voorbarig. Er bestaan namelijk belangrijke risico's. Wat participatie betreft, biedt de Ow soms minder mogelijkheden dan voorheen. Dit geldt voor het indienen van zienswijzen op het voornemen een MER op te stellen, hetgeen onder het huidige omgevingsrecht nog mogelijk is, maar met de komst van de Ow niet meer. Verder biedt het wetsvoorstel te weinig waarborgen om omgevingswaarden te behalen. Indien een omgevingswaarde niet is behaald, dan dient er een programma te worden opgesteld. Er geldt een uitvoeringsplicht voor de maatregelen uit deze programma's, maar deze uitvoeringsplicht is afhankelijk gesteld van de instemming van het betreffende bestuursorgaan. Indien alsnog niet voldaan wordt aan een omgevingswaarde, dan moet het programma worden aangepast zodat binnen een 'passende termijn' wel aan de omgevingswaarde wordt voldaan. De mogelijke duur van een 'passende termijn' is evenwel in nevelen gehuld. Indien nog steeds niet aan de omgevingswaarde wordt voldaan, dan kan het vertegenwoordigende orgaan het uitvoerende orgaan hierop aanspreken of kan in het kader van interbestuurlijk toezicht tevens indeplaatsstelling door een ander bestuursorgaan plaatsvinden. Onzes inziens biedt dit te weinig waarborgen om de realisatie van omgevingswaarden vast te stellen. Als het vertegenwoordigend bestuursorgaan of het toezichthoudend bestuursorgaan nalaat om het uitvoerende orgaan aan te spreken, dan kan er een iteratief proces ontstaan van het steeds maar aanpassen van programma's als de omgevingswaarden niet worden behaald. Het opleggen van een geldelijke boete door de rechter als ultimum remedi- 
um biedt onzes inziens meer waarborgen. Om het halen van omgevingswaarden daadwerkelijk te kunnen waarborgen is rechtsbescherming dus een middel dat daaraan kan bijdragen. Het is van belang dat ook burgers het halen van omgevingswaarden rechtens afdwingbaar kunnen maken. Daarbij is het opvallend dat er de laatste jaren juist een (wetgevende) tendens is om de rechtsbescherming voor burgers in te perken. Hierbij wijzen wij op het per 1 januari 2013 voor het gehele bestuursrecht geldende relativiteitsbeginsel, ${ }^{135}$ en de tendens om steeds meer activiteiten - waar voorheen een vergunningplicht ${ }^{136}$ voor gold - onder algemene regels te brengen, zodat er geen (bestuursrechtelijke) rechtsbescherming meer tegen open staat. ${ }^{137}$

Het grootste risico in het kader van het waarborgen van duurzaamheid vormt de geboden flexibiliteit van het wetsvoorstel. ${ }^{138} \mathrm{De}$ 'fysieke leefomgeving' is het criterium voor diverse instrumenten van de Ow. Waar onder huidig recht bij het bestemmingsplan 'een goede ruimtelijke ordening' de centrale norm is, is bij bijvoorbeeld het omgevingsplan de 'fysieke leefomgeving' de norm. Deze integrale benadering neemt onzes inziens echter niet weg dat er inhoudelijk gezien nog steeds dezelfde belangenafweging zal moeten plaatsvinden. ${ }^{139} \mathrm{Er}$ is in de memorie van toelichting helaas geen aandacht besteed aan een prioritering van belangen. Waterveiligheid zal doorgaans in de belangenafweging een doorslaggevende rol spelen. Het is van belang om bij planologische besluitvorming rekening te houden met waterveiligheidsaspecten bij het aanwijzen van bestemmingen en het toestaan van ruimtelijke ontwikkelingen bij waterkeringen. Dat dit noodzakelijk is (en in het algemeen belang is) zal niemand ontkennen. Maar hoe speelt het criterium van de 'fysieke leefomgeving' een rol bij bijvoorbeeld eventuele toestemmingen voor het winnen van schaliegas? Hoe weeg je bij het vaststellen van een omgevingsplan, het verlenen van een projectbesluit of omgevingsvergunning bodem- en (grond)waterkwaliteit af tegen andere belangen? Kan hier het duurzaamheidsbelang (zie bijvoorbeeld de art. 1.2 en $1.3 \mathrm{Ow}$ ) ook een rol spelen? Hoe motiveer je dat het ene belang de ene keer prevaleert en het andere belang de andere keer? Integratie is vanuit duurzaamheidsperspectief iets om na te streven, maar het moet bij concrete besluitvorming

135. Art. 8:69a Awb.

136. En dus rechtsbescherming mogelijk was.

137. Zie A.P.W. Duijkersloot, A.A.J. de Gier, F.A.G. Groothuijse, H.F.M.W. van Rijswick \& R. Uylenburg, Algemeen geregeld, goed geregeld? Een analyse van onderzoeken naar de werking van algemene regels in het licht van de doelstellingen voor de vernieuwing van het omgevingsrecht, $M$ en R 2011-9, p. 576-585.

138. Vgl. Ch. W. Backes, Het voorstel voor een Omgevingswet - goed voor natuur en milieu?, TO 2013, nr. 3, p. 99-112. Backes heeft soortgelijke bezwaren wat betreft het belang van natuur en landschap. Uylenburg betoogt dat flexibiliteit in het omgevingsrecht niet altijd wenselijk is (zie: R. Uylenburg, Flexibel wat kan, M en R 2014-64, p. 319-320).

139. De Raad van State heeft in zijn advies op het wetsvoorstel kritiek geuit op de mogelijkheid tot belangenafweging. Volgens de Raad van State biedt het wetsvoorstel geen houvast voor een integrale afweging en is 'niet duidelijk [...] wie welke instrumenten wanneer mag inzetten en onder welke voorwaarden' (Kamerstukken II 2013/14, 33 962, nr. 4, p. 14). niet tot een vergaarbak van belangen leiden die naar eigen goeddunken van het bevoegd gezag kunnen worden gebruikt bij de motivering van besluiten.

De flexibiliteit die wordt geboden met betrekking tot de twee primaire doelen van de $\mathrm{Ow}$ is onzes inziens ook problematisch. Het primaire doel dat een veilige en gezonde fysieke leefomgeving en een goede omgevingskwaliteit waarborgt, kan worden afgewogen tegen het andere primaire doel betreffende het gebruik van de fysieke leefomgeving voor maatschappelijke functies. Niet is verzekerd dat het ene belang zwaarder weegt dan het andere belang. Indien een bestuursorgaan beargumenteert dat met het oog op duurzame ontwikkeling het gebruik van de fysieke leefomgeving voor maatschappelijke functies zwaarder weegt dan het belang van een veilige en gezonde fysieke leefomgeving dan kan dit een economische winst opleveren, maar tevens een ecologische en/of sociaal verlies. Het feit dat de belangenafweging tussen deze twee primaire doelen van de $\mathrm{Ow}$ plaatsvindt in het kader van duurzame ontwikkeling wil derhalve niet verzekeren dat duurzaamheid - en dan met name de ecologische en sociale dimensie - altijd gewaarborgd is. Het zwaarder laten wegen van het belang van een veilige en gezonde fysieke leefomgeving en een goede omgevingskwaliteit, dan het belang van het gebruik van de fysieke leefomgeving voor maatschappelijke functies, biedt onzes inziens meer waarborgen voor duurzaamheid. Naast omgevingswaarden kan een bestuursorgaan, al gezegd, ook 'andere doelstellingen voor de fysieke leefomgeving' opstellen, die ook verband houden met de twee primaire doelstellingen. Deze mogelijkheid is echter wel zeer vaag geformuleerd; het biedt geen duidelijke handvatten hoe deze doelstellingen geoperationaliseerd kunnen worden.

Het streven naar transitie naar een duurzame samenleving is met deze geboden flexibiliteit niet gediend. Verder geeft het de bestuursorganen en burgers onvoldoende houvast en sturing voor de praktijk. Veel middelen die kunnen worden ingezet voor duurzaamheidsbelangen zijn dus te vrijblijvend. Het wetsvoorstel biedt daarmee een belangrijke stimulans, maar onvoldoende waarborgen om de transitie ook daadwerkelijk te bewerkstelligen.

Verder blinkt de Ow niet altijd uit in duidelijkheid. 'Coactorschap' klinkt bijvoorbeeld mooi, maar biedt naar onze mening echter onvoldoende houvast voor de praktijk. Een vergelijking is hier snel gemaakt met het bekende fenomeen van de 'tragedy of the commons'. Deze theorie komt er kort gezegd op neer, dat indien er een gezamenlijke verantwoordelijkheid bestaat, niemand uiteindelijk meer verantwoordelijkheid neemt. ${ }^{140}$ Integratie en coördinatie zouden onzes inziens niet zover moeten strekken; daar wordt het duurzaamheidsbelang ook niet mee gediend. Op zijn minst dienen taken en bevoegdheden nader geconcretiseerd te worden (onder

140. T. Dietz, E. Ostrom \& P.C. Stem, The struggle to govern the commons, 2003-12/302, p. 1907-1912. 
welke voorwaarden mag, welk bestuursorgaan, van welke bevoegdheden gebruik maken?). Eigen verantwoordelijkheden, gedeelde verantwoordelijkheden, burgerplichten en zorgplichten zijn normatieve doelstellingen, waar naar gestreefd zou moeten, of kunnen worden, maar waarborgen de duurzaamheidsbelangen geenszins. Beleidsmatig kan het uitgangspunt van 'co-actorschap' naar onze mening een rol spelen, maar het uitgangspunt van wet- en regelgeving dient gebaseerd te zijn op een duidelijke bevoegdheden- en verantwoordelijkheidsverdeling, in overeenstemming met het legaliteitsbeginsel. Vanuit juridisch oogpunt moet duidelijk zijn, welk bestuursorgaan welke bevoegdheid heeft en wie waarop dus kan worden aangesproken.

Al met al besteedt de Ow veel aandacht aan duurzaamheid. Er bestaat echter een risico dat economische belangen de boventoon zullen voeren bij de belangenafweging van bestuursorganen. Om dit risico te verhelpen moet het belang van een veilige en gezonde fysieke leefomgeving en goede omgevingskwaliteit een zwaarder gewicht toegekend worden bij de belangenafweging en moet het halen van omgevingswaarden wettelijk gewaarborgd zijn door de mogelijkheid te bieden om via de rechter geldelijke boetes op te leggen. Flexibiliteit kan voordelen opleveren, maar het uitgangspunt van wet- en regelgeving dient gestoeld te blijven op een duidelijke bevoegdheden- en verantwoordelijkheidsverdeling, in overeenstemming met het legaliteitsbeginsel. Pas dan kan duurzaamheid voldoende worden gewaarborgd, zodat toekomstige generaties ook in hun behoeften kunnen voorzien. 